\title{
Effect of Visible Light on Surface-Attached and Suspended Heterotrophic Bacteria in a Typical Household Rainwater Harvesting Tank
}

\author{
Vonihanitriniaina Andriamanantena R. ${ }^{1}$, Mikyeong Kim ${ }^{2}$ and Mooyoung Han ${ }^{1, * \mathbb{D}}$ \\ 1 Department of Civil \& Environmental Engineering, Seoul National University, Seoul 08826, Korea; \\ ramasiarisoadiamondra@gmail.com \\ 2 Next Green Lab, Incheon 22736, Korea; mkkim337@gmail.com \\ * Correspondence: myhan@snu.ac.kr; Tel.: +82-1043540946
}

check for updates

Citation: Andriamanantena R., V.; Kim, M.; Han, M. Effect of Visible Light on Surface-Attached and Suspended Heterotrophic Bacteria in a Typical Household Rainwater Harvesting Tank. Sustainability 2021, 13, 5410. https://doi.org/10.3390/ su13105410

Academic Editor: Fernando António Leal Pacheco

Received: 26 March 2021

Accepted: 7 May 2021

Published: 12 May 2021

Publisher's Note: MDPI stays neutral with regard to jurisdictional claims in published maps and institutional affiliations.

Copyright: (C) 2021 by the authors. Licensee MDPI, Basel, Switzerland. This article is an open access article distributed under the terms and conditions of the Creative Commons Attribution (CC BY) license (https:/ / creativecommons.org/licenses/by/ $4.0 /)$.

\begin{abstract}
Rainwater harvesting (RWH) systems can be used to mitigate global water crises; however, they have been poorly received by communities because of the sub-standard quality of harvested water. Heterotrophic bacteria present in the water can degrade the water's microbiological quality and create health issues. Moreover, exposure to visible light can affect both suspended and surfaceattached heterotrophic bacteria, a phenomenon that is poorly investigated. This study explored the effect of visible light on surface-attached heterotrophs (SAB) and suspended heterotrophs (SB) in an RWH tank for a period of three months. The SAB plate counts were observed to be significantly higher in the tank exposed to sun (TES) than in the tank not exposed to sun (TNES). Furthermore, the SB plate counts in the TNES reduced 10 folds faster than in the TES, especially at the top and middle levels. When exposed to visible light, the phototrophs present in the water sustained the heterotrophs by producing nutrients via photosynthesis. Based on the findings of this research, this paper recommends providing shade to the tanks that are exposed to sunlight. Additionally, it suggests not to disinfect the tank because it leads to a decrease in the self-purification effect of microbes.
\end{abstract}

Keywords: visible light; rainwater harvesting; heterotrophs; biofilm

\section{Introduction}

Water is critical for the survival of human beings. In developing nations, a constant population growth corresponds to an increased pressure on water resource and water consumption [1,2]. Thus, millions of people live in areas with extreme water vulnerability and do not have access to clean water [2]. Furthermore, it has been predicted that by 2050, more than half of the global population will live in areas that suffer from water scarcity at least one month each year [3]. Serious actions to tackle these underlying threats should then be implemented through improvement of water management, increased efforts of water conservation, and adoption of nature-based solutions [3], one of which is via RWH [4].

RWH technology consists of collecting rainwater from a roof or other catchment surface and directing it into a storage area [5]. This storage area ranges from a simple rainwater barrel to a more complex multiple tank system [6]. Despite the inclusion of simple methods, RWH is not widely used in developing countries due to the excess cost of storage tank, the uncertainty of water quality, and poor installation or maintenance [5,7]. In households that use RWH, cheap recycled or scavenged items like plastic barrels, jerrycans, or plastic drums, that allow for the penetration of visible light, are often used in lieu of more ideal opaque tanks $[4,8]$ to help address water shortage for both potable and non-potable purposes [5].

A common issue with RWH, nonetheless, is the quality of rainwater harvested. Because of the presence of dry and wet particles that settle on the roof catchment, such as dust 
and bird droppings, many researchers have observed poor quality of harvested water $[9,10]$ which may contain pathogens that are harmful to human health [11]. Few studies, which utilized opaque and large storage tanks, have investigated the factors affecting microbial growth in RWH [12-14]. However, to the knowledge of the authors, no research has been done on the quality of rainwater using storage items that households in developing countries commonly use, which are cheaper, more accessible, and allow for the penetration of visible light [8]. Thus, the purpose of this paper is to fill the current knowledge gap on the microbial water quality of rainwater kept in storage of small capacity allowing light penetration. The quality of harvested rainwater is influenced by several physicochemical, spatial, temporal, and microbiological factors $[15,16]$. Baseline low concentration of total dissolved solids and organic carbon in rainwater has the potential to inhibit growth of SB [17]. On the other hand, high water temperature inside storage tanks can stimulate bacterial proliferation [16]. The number of bacteria in rainwater also differ depending on the storage water depth and over time for both suspended as well as SAB [18-20]. In addition, while SAB in tap water have been found to carry waterborne pathogens in drinking water distribution systems [21], several studies have observed a positive effect of SAB particularly on harvested rainwater quality [15,17]. The advantages, however, were found only in investigations that involved stored rainwater not exposed to visible light.

A study by Kim and Han (2011) observed that after inoculating Pseudomonas aeruginosa in rainwater storage with $\mathrm{SAB}, 99 \%$ of the Pseudomonas was removed after five days in fullscale tanks [17]. In addition, Coombes et al. (2006) stated that in underground rainwater tanks, SAB removed toxic metals and compounds from the water column by playing the role of a bioreactor [12]. Suspended heterotrophic bacteria can also digest dissolved organic compounds, attach to the SAB, and die naturally due to starvation [12,22] Thus, in a RWH tank that is not exposed to visible light, SAB improves microbiological water quality $[19,22]$. Although these studies highlight the potential benefits of SAB, studies on their growth and their effect on heterotrophic bacteria in stored rainwater exposed to visible light are lacking. Nevertheless, the influence of visible light on water quality has been investigated in other sources of water.

Research on the effects of visible light on SB present in aquatic ecosystem yielded conflicting results. Visible light was found to hinder microbial growth by producing reactive oxygen species, which cause oxidative damage in bacterial cells [23,24]. However, a literature review done by Ruiz-Gonzales et al. (2013) discussed the effects of sunlight on heterotrophic bacterial activity, suggesting that visible light induces photosynthesis, which affects the quantity of organic compounds passing through the microbial food chains. The photochemical transformation of dissolved compounds in the water in turn increases the amount of food that is available for the existing heterotrophic bacteria, leading to its multiplication [25]. Furthermore, a research done by Schmidt et al. (2018) showed that $\mathrm{SAB}$ in water exposed to visible light, despite its stable counts over time, were significantly higher in number compared to the non-exposed condition at the end of the study period [26]. These findings, however, are yet to be seen in studies on harvested rainwater.

The objectives of this paper are to investigate the effects of visible light on both microbial and physicochemical properties of water in rainwater harvesting tanks of small capacity and to suggest a possible practical way how to maintain the microbial water quality of household rainwater tanks in developing countries and developed countries as well.

\section{Materials and Methods}

\subsection{Experimental Setup}

Two $34 \mathrm{~L}$ acrylic tanks, having a diameter of $25 \mathrm{~cm}$ and a height of $70 \mathrm{~cm}$ each, were fabricated with a tap at the bottom. As this study focused on the effect of visible light, a PVC coating (ORACAL 8300) that was purchased from Orafol, Germany was used to prevent the penetration of ultraviolet (UV) radiation into the tank. The two tanks were first 
washed with detergent and then rinsed with double-distilled water. Furthermore, they were sterilized with $70 \%$ ethyl alcohol.

Coupons were made (each with a surface area of $16 \mathrm{~cm}^{2}$ ) using polyethylene terephthalate (PET), with each coupon having a dimension of $2 \times 4 \mathrm{~cm}$. After sterilizing with $70 \%$ ethyl alcohol, three of these coupons were attached to a single sterile fishing line at different heights that corresponded to the top water level (T) (at a depth of $15 \mathrm{~cm}$ from the water surface), middle water level (M) (at a depth of $35 \mathrm{~cm}$ from the water surface), and bottom water level (B) (at a depth of $55 \mathrm{~cm}$ from the water surface), as illustrated in Figure 1 . T was set at $15 \mathrm{~cm}$, as many researchers have shown that solar disinfection is ineffective at depths greater than $10 \mathrm{~cm}$ [27]. Furthermore, 24 strings were tied vertically with three coupons each $(\mathrm{T}, \mathrm{M}, \mathrm{B})$ to a cable tie, as shown in Figure 1.

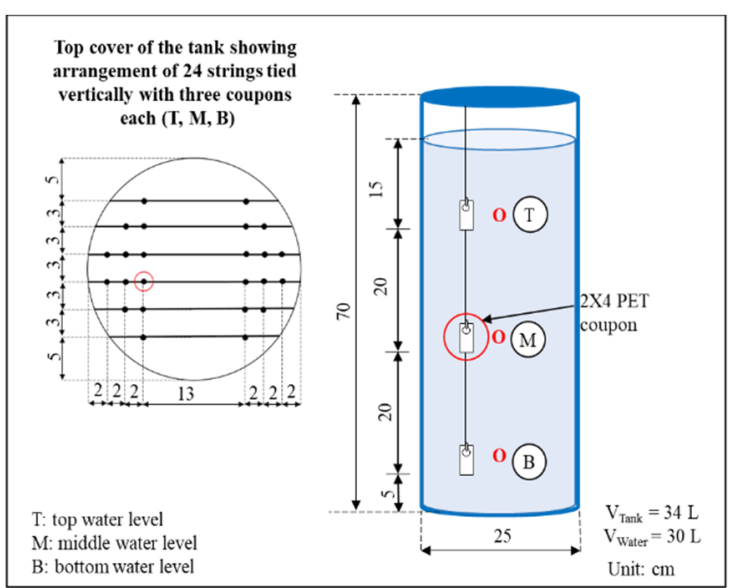

(a)

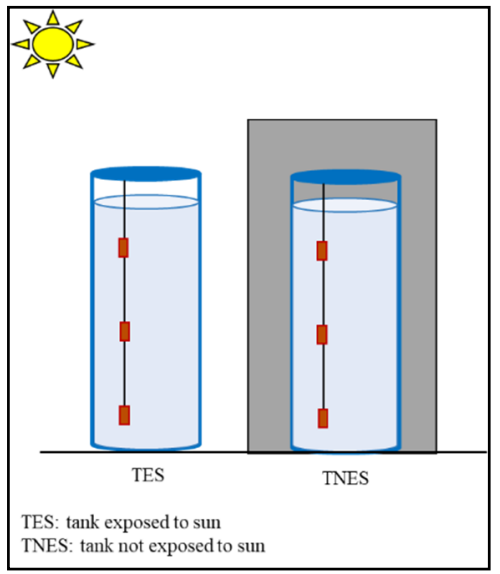

(b)

Figure 1. Experimental setup of sampling coupons in rainwater tanks (a) Top and side view of the tank storage, (b) The effect of sunlight.

Rainwater was collected from the RWH system with a first flush tank in building number 39 at Seoul National University, South Korea, and introduced into the acrylic tank until the water level reached $30 \mathrm{~L}$. The physiochemical characteristics of the water source are as follow: $\mathrm{pH}$ and temperature were $7.83^{\circ}$ and $22^{\circ}$, the concentration of dissolved oxygen was $5.28 \mathrm{mg} \mathrm{L}^{-1}$, and the level of total dissolved solids were $57 \mathrm{mg} \mathrm{L}^{-1}$. The total phosphorous (TP) and total nitrogen (TN) were very low $<0.01 \mathrm{mg} \mathrm{L}^{-1}$ and $1.64 \mathrm{mg} \mathrm{L}^{-1}$, and the total organic carbon were $2.58 \mathrm{mg} \mathrm{L}^{-1}$.

This procedure was repeated for the other tank. Then, one tank was kept on the roof of building number 35 at Seoul National University and the other tank was kept inside a room with no openings to provide a dark environment. The experiment was conducted from July to September 2020, that is, during the summer. The average meteorological condition and the visible light intensity surrounding the study area are as follows: the temperature was $27.28 \pm 1.34^{\circ} \mathrm{C}$, the humidity was $58 \pm 21 \%$, and the visible light intensity was $70.12 \pm 9.20 \mathrm{~kW} / \mathrm{m}^{2}[28]$.

\subsection{Sampling and Collection of Coupon}

Water samples $(20 \mathrm{~mL})$ were collected weekly at each level using a sterile $10 \mathrm{~mL}$ pipette, corresponding to the water level of the coupon. The collected water was then poured into a $50 \mathrm{~mL}$ sterile conical plastic tube. During the experimental period, the tanks were not refilled with water. The volume of the water sample did not exceed $1 \mathrm{~L}$, and water loss was minimized by placing a parafilm at the edge of the tanks. At the end of the experiment, less than $2 \mathrm{~cm}$ of the water was depleted.

Every week, two strings, located at the opposite ends of the tank, were removed and washed with $5 \mathrm{~mL}$ of sterile phosphate buffered saline (PBS) to separate the non-attached bacteria. Then, three coupons (of T, M, and B) were placed inside the sterile conical plastic 
tubes filled with $20 \mathrm{~mL}$ of PBS to investigate the microbial properties. Another three coupons were placed in sterile Petri dishes until they were assessed for biomass.

\subsection{Bacterial Enumeration}

The culturable suspended heterotrophic bacteria plate counts in the collected water samples were assessed using $3 \mathrm{M}$ petrifilm Aqua Heterotrophic Count (AQHC) plates. The collected water samples were diluted using sterile distilled water to measure the plate counts (15-200 colonies). After dilution, $1 \mathrm{~mL}$ of the diluted solution was spiked onto the AQHC plates and evenly spread using a spreader that was provided with the AQHC plates. The spiked AQHC plates were then incubated at $37^{\circ} \mathrm{C}$ for $48 \mathrm{~h}$. After incubation, the number of colony-forming units (CFU) of each plate was counted. The plate counts were performed in triplicate, and the average CFUs were expressed in CFU $/ \mathrm{mL}$.

The bacteria had to be detached from the surface in order to measure the SAB. To detach them, this study used the method described by Kobayashi et al. (2009) [29]. First, test tubes containing the coupons were shaken using a vortex shaker (SI-0246A VortexGenie-2, Scientific Industries Inc., USA) for $3 \mathrm{~min}$, and then immersed in a sonication bath (SAE-HAN Ultrasonic cleaner SH-1025, SAE HAN Ultrasonic Co., Jongno-Gu, Seoul, Korea) for $15 \mathrm{~min}$ at $60 \mathrm{~Hz}$. The optimum sonication time was determined during the preliminary study to maximize the detachment.

During the preliminary study, the sonication bath was on for time: 5, 10,15, 20, and $25 \mathrm{~min}$. After $5 \mathrm{~min}, 1 \mathrm{~mL}$ of the solution was spiked on the petrifilm in triplicate. We repeated the process for the different time. The number of CFU did not increase from 15 to $20 \mathrm{~min}$. Therefore, $15 \mathrm{~min}$ was retained as the optimum sonication time.

After the sonication bath, the number of CFUs in the water (detached from the coupon) was measured using the same method described for the SB plate counts. However, for the SAB, the number of colonies observed was multiplied by the volume of the PBS and divided by the surface area of the coupon to estimate the number of CFUs per unit area of the coupon. Therefore, all the $\mathrm{SAB}$ plate counts are expressed in $\mathrm{CFU} / \mathrm{cm}^{2}$ units. Every bacterial enumeration was made in triplicate.

\subsection{Total Biomass Quantification}

Total amount of biomass is the structure formed by SAB, dead cell, and extracellular substance [30]. The quantification of total amount of biomass is an indirect way to assess the presence of bacteria attached to a surface [31] The biofilm formed by SAB was estimated using the crystal violet staining assay, following the method used by Stiefel et al. (2016) [30]. The coupon collected in the Petri dish was dried at $25^{\circ} \mathrm{C}$ in the room. Then, $5 \mathrm{~mL}$ of $0.5 \%$ crystal violet $(\mathrm{CV})$ was added to the Petri dish and the coupon was immersed for $30 \mathrm{~min}$. A $0.5 \%$ CV solution was prepared following the Cold Spring Harbor Laboratory protocol [32]. Additionally, crystal violet powder (Daejung Chemicals \& Metals, South Korea) was mixed with $20 \mathrm{~mL}$ of methanol (Daejung Chemicals \& Metals, South Korea) and $80 \mathrm{~mL}$ of double-distilled water. The coupons were retrieved from the staining solution and washed thrice with $5 \mathrm{~mL}$ of sterile distilled water. After the coupons were dried at $25^{\circ} \mathrm{C}$ in the room, $5 \mathrm{~mL}$ of $96 \%$ ethanol was added to dissolve the surface-attached bacteriabound CV. The Petri dish was gently shaken after the introduction of ethanol. Alcohol solution containing the stain was analyzed using a water analyzer and spectrophotometer (HS-3300, Humas, Daejeon, Korea). Absorbance corresponding to a wavelength of 595 $\mathrm{nm}$ was measured (with a standard error of $1 \%$ of absorbance), which was an indicator of the biomass.

\subsection{Measurement of Physiochemical Parameters}

The $\mathrm{pH}$ (with a standard error of \pm 0.02 ) and temperature (with a standard error of \pm 0.2 ) of rainwater were measured using a pH meter (HM 31 P, TOADKK, Japan). Furthermore, total dissolved solids (TDS) (with a standard error of \pm 0.002 ) was measured using an HM Digital COM-300 EC TDS pH 4 in 1 Combo Meter (New York, NY, USA). Dissolved 
oxygen (DO) (with a standard error of $\pm 0.1 \mathrm{mg} / \mathrm{L}$ ) was measured using an optical dissolved oxygen meter (ProODO, YSI, Yellow Springs, OH, USA). The concentration of total organic carbon in stored rainwater was measured with (Shimdazu total organic carbon analyzer ASI-V auto sampler).

\subsection{Statistical Analysis}

Data were first normalized by a log transformed due to the assumption required in parametric statistical analysis methods such as t-test and ANOVA [33,34]. Then it was subjected to two-way repeated measures ANOVA, and paired $t$-tests were performed using this software at a $95 \%$ confidence interval. Two fixed factors were considered: time with 12 levels (1-12 weeks) and water depths (top, middle, and bottom). Statistical analyses were performed on the data that were converted to a logarithmic scale using SAS University edition software. A non-linear regression with exponential function was performed to assess the decay rate of the $\mathrm{SAB}$, total amount of biomass and $\mathrm{SB}$.

\section{Results and Discussion}

\subsection{Effect of Visible Light on $S A B$}

\subsubsection{Effect of Visible Light on SAB at Different Water Depths}

All the coupons that were analyzed in this study contained heterotrophic bacteria on their surfaces. The surface-attached heterotrophic bacterial counts are shown in Figure 2.

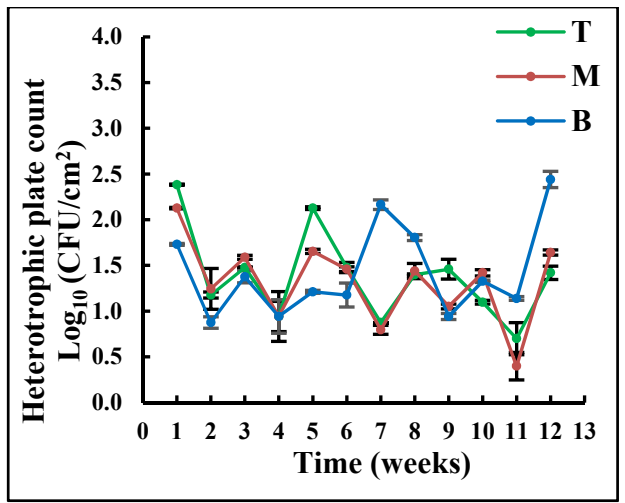

(a)

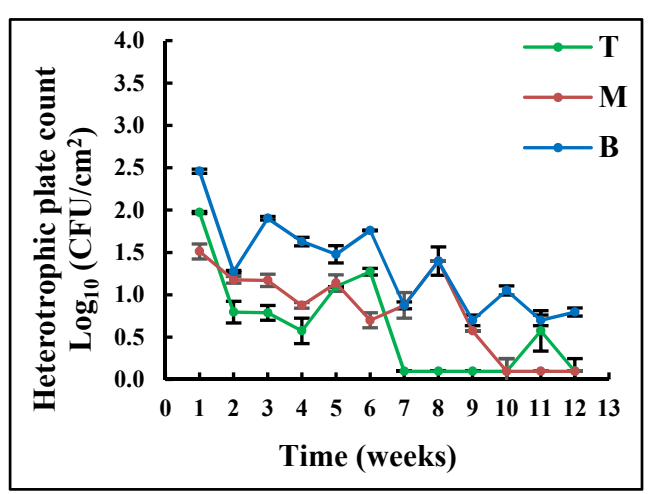

(b)

Figure 2. Variation of surface-attached heterotrophic bacteria (a) in the tank exposed to sun and (b) in the tank not exposed to sun at different water depths (T: top, M: middle, and B bottom).

Exposure to visible light had a significant effect on the amount of surface-attached bacteria in the tank $(p \leq 0.02)$. While the number of heterotrophic bacteria was relatively stable in the TES, it decreased in the TNES. The stability of heterotrophic bacteria is probably caused by the higher availability of food produced by phototrophs during photosynthesis [26]. This hypothesis is corroborated by a significant difference in the concentration of total organic carbon in the two tanks, illustrated in Figure 3, (Student $t$-test $p<0.05$ ). According to Schmidt et al. (2018), phototrophic bacteria in biofilms contribute to their stabilization and cultivation; additionally, low light intensity results in a significant reduction in biofilm development [26].

Figure 2 also shows that the time trends in SAB plate count, with changes observed in two stages in both tanks: (1) from the 1st week until the 6th week, then (2) from the 6th week until the end of the experiment. This effect of time on the surface-attached plate counts is significant in the TES and TNES, Greenhouse-Geisser F $(2.33)=46.303, p<0.01$ and $\mathrm{F}(2.33)=90.415, p<0.01)$, respectively. In this regard, Kim et al. (2016) and Amauri et al. (2020) both reported that the accumulation of bacteria on the surface is a dynamic process involving the adhesion, growth, and maturation of surface-attached structures $[14,35]$. 
The main effect of water depth on the average $\mathrm{SAB}$ plate counts across the time is also significant. In the initial phase, SAB plate counts at the top $\left(1.51 \log _{10} \mathrm{CFU} / \mathrm{cm}^{2}\right)$ and middle $\left(1.46 \log _{10} \mathrm{CFU} / \mathrm{cm}^{2}\right)$ were higher compared to bottom level $\left(1.21 \log _{10} \mathrm{CFU} / \mathrm{cm}^{2}\right)$. Van der Merwe et al. (2013) reported a similar trend, with higher bacterial attachment at the top and middle levels [14]. During the second phase, however, the number of SAB at the bottom level increased. Towards the end, the concentration of $\mathrm{SAB}$ at the bottom surpassed both the top and middle level SAB plate counts. The pairwise comparisons indicated a significant difference only between the middle and bottom water level $(p \leq 0.09)$. Spinks et al. (2007) and Kim et al. (2016) observed that the sedimentation of particle-attached bacteria induced a better development of biofilm at the bottom level of an underground rainwater tank $[13,19]$. Another possible explanation is the biota exchange between the sludge and $\mathrm{SAB}$ at the bottom resulting in increased count over time, as also argued by Tu et al. (2020) in their study on biofilm formation on microplastics [36]. This strongly supports the results of this study. A similar sedimentation process took place in TNES, which is responsible of statistically variation between the different water depths $(p<0.05)$. Some authors also argued that the bacterial count differences between levels are due to the water temperature gradient [19], but no significant differences in temperature were observed in the current study. However, temperature was taken only once weekly, which might not measure precise temperature gradient.

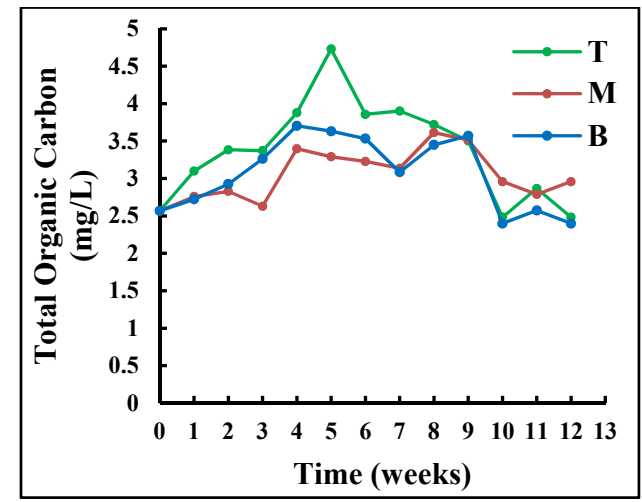

(a)

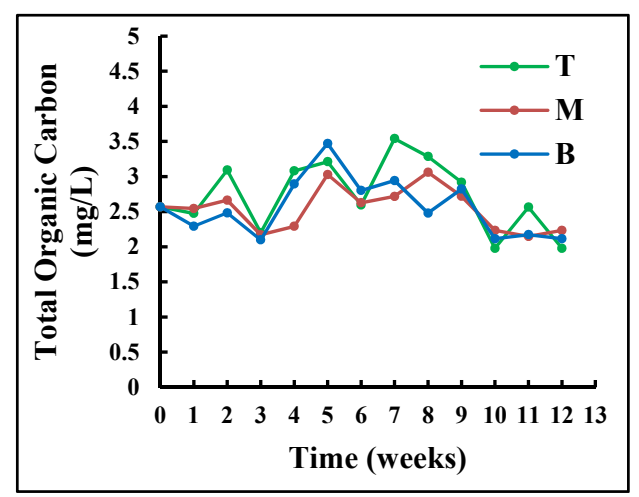

(b)

Figure 3. Variation of concentration of total organic carbon (a) in the tank exposed to sun and (b) in the tank not exposed to sun at different water depths (T: top, M: middle, and B bottom).

A non-linear regression with an exponential function was calculated to determine the decay rate of $\mathrm{SAB}$ at the top, middle and bottom level as seen in Table 1. The regression equation was $\mathrm{y}=\mathrm{A} \times \mathrm{e}^{(\mathrm{b} . \mathrm{t})}, \mathrm{b}$ represents the decrease of the bacteria per day. The coefficient of determination $\mathrm{R}^{2}$ and the $95 \%$ confidence interval (CI) for the decay rate are presented in the Table 1.

Table 1. Growth and decay rate, coefficient of determination $\mathrm{R}^{2}$, and $95 \% \mathrm{CI}$ of surface-attached heterotrophic bacteria in tank exposed to sun and non-exposed to sun at different water depths.

\begin{tabular}{|c|c|c|c|c|c|c|}
\hline \multirow[t]{2}{*}{ Water Depths } & \multicolumn{3}{|c|}{ Tank Exposed to Sun } & \multicolumn{3}{|c|}{ Tank Not Exposed to Sun } \\
\hline & Rate $\left(d^{-1}\right)$ & $\mathbf{R}^{2}$ & $95 \% \mathrm{CI}$ & Rate $\left(d^{-1}\right)$ & $\mathbf{R}^{2}$ & $95 \% \mathrm{CI}$ \\
\hline Top & -0.34 & 0.60 & {$[-0.676-0.010]$} & -0.33 & 0.91 & {$[-0.462-0.192]$} \\
\hline Middle & -0.17 & 0.41 & {$[-0.279-0.072]$} & -0.03 & 0.53 & {$[-0.050-0.020]$} \\
\hline Bottom & 0.26 & 0.66 & {$\left[\begin{array}{lll}0.093 & 0.417\end{array}\right]$} & -0.25 & 0.80 & {$[-0.367-0.137]$} \\
\hline
\end{tabular}

The extremely slow growth rates, as shown in Table 1 confirmed again the effect of visible light on the surface-attached bacteria. Without visible light exposure, it had a similar pattern as that of the first phase, except that the number of surface-attached 
bacteria declined after the 6th week, with a higher decay rate being observed at the top and middle levels.

\subsubsection{Effect of Visible Light on Total Biomass of SAB at Different Water Depths}

Figure 4 shows that the amount of total biomass that was exposed to visible light was significantly larger than that of the non-exposed tank. Visible light induces the production of organic compounds necessary for the metabolism of heterotrophic bacteria as seen in Figure 3. Augusti et al. (2020) and Music et al. (2019) have emphasized that light is a primary energy source for autotrophic organisms, linking photosynthesis directly to the growth of biomass and uptake of nutrients [37,38]. In addition, the secretion of the extracellular substance bu SAB might also contribute to the disparity between the amount of total biomass in TES and TNES. Schmidt et al. (2018), found a higher amount of extracellular polymeric substances with light exposure [26].

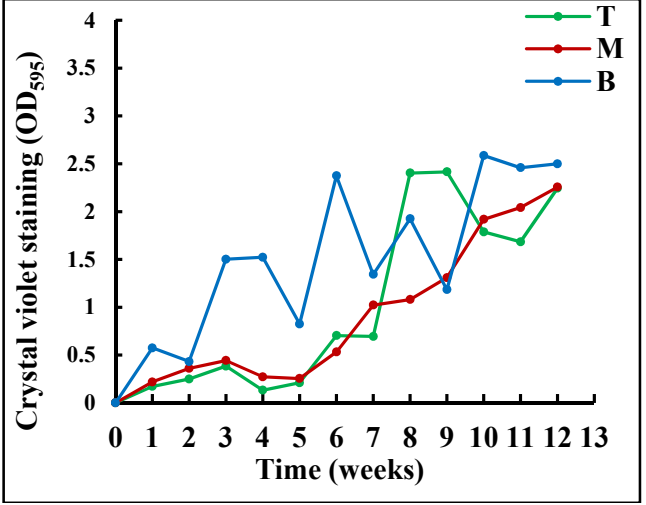

(a)

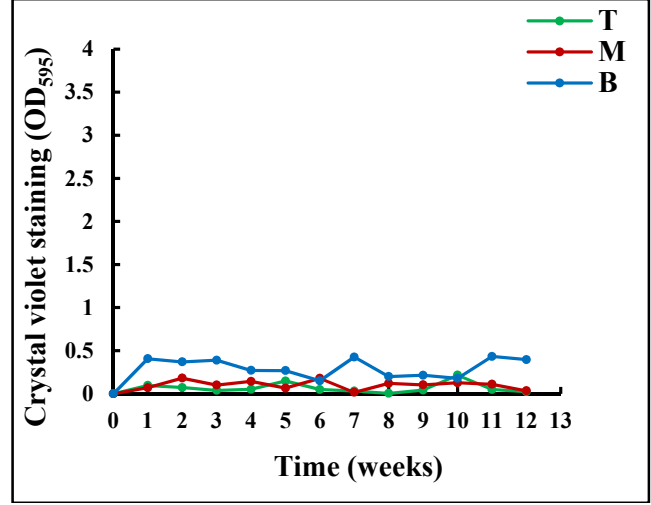

(b)

Figure 4. Variation of the total SAB biomass (a) in the TES and (b) in the TNES at different water depths over time (T: top, M: middle, and B bottom).

Storage time also had a significant impact on the variation of the amount of total biomass of surface-attached in TES (Figure 4). Until the 6th week, the augmentation of total biomass was slow, and then it showed a rapid increase. These temporal dynamics of the biomass pattern on the PET surface were in accordance with those of a previous study done by Tender et al. (2017) [39]. The first stage was argued to due to bacterial colonization and early biofilm formation. Over time, bacterial proliferation intensified, and biofilms grew in planar expansion and thickened [39]. Moreover, the faster growth at the bottom level during the early phase can be explained by the integration of dead cells, a source of DOM for heterotrophic bacteria that contribute to total biomass [25], into the biofilm due to sedimentation [19]. Indeed, this study has added to the literature that highlight effect of time on biomass accumulation [36].

In the TNES, the variation of the amount of biomass overtime was almost constant, but there were significant differences in biomass count in water depth as shown in Figure 4 and in Table 2. The total biomass at the bottom level was significantly higher than that at the upper level Stiefel et al. (2016) stated that the total amount of biofilm is formed by live cells, dead cells, and extracellular substances [30]. Dead cells settle and accumulate at the bottom of the tank [28]. Furthermore, the placement of the coupon at near the bottom of the tank might have enhanced biota exchange [36].The growth rate of the amount of biomass was estimated by non-linear regression for TES. The statistical analysis result was summarized in Table 2. The regression analysis of total amount of biomass revealed that there is no correlation between time and total amount of biomass. 
Table 2. Comparison of the growth rate, coefficient of determination $\mathrm{R}^{2}$, and $95 \% \mathrm{CI}$ in the TES at different water depths.

\begin{tabular}{cccc}
\hline \multirow{2}{*}{ Water Depths } & \multicolumn{3}{c}{ Tank Exposed to Sun } \\
\cline { 2 - 4 } & Rate (d-1) & $\mathbf{R}^{\mathbf{2}}$ & $\mathbf{9 5 \%} \mathbf{C I}$ \\
\hline Top & 0.03 & 0.67 & {$[0.0090 .043]$} \\
Middle & 0.03 & 0.94 & {$[0.0230 .004]$} \\
Bottom & 0.01 & 0.59 & {$[0.0050 .023]$} \\
\hline
\end{tabular}

\subsection{Effect of Visible Light on $S B$}

Figure 5 shows the comparison of SB between TES and TNES over time and different water depths. The decay rate of heterotrophic bacteria summarized in Table 3 $\left(0.024 \mathrm{CFU} \mathrm{day}{ }^{-1}\right)$ in the TNES was significantly higher than that in the TES $(0.004 \mathrm{CFU}$ day $^{-1} ; p<0.05$ ). According to Ruiz-Gonzalez et al. (2013) and Hameed et al. (2020), visible light triggers the uptake of DOM and cell division of heterotrophic bacteria [25,40]. Therefore, a decrease in bacterial count was alleviated by the production of new cells. In addition, with visible light exposure, phototrophs produce carbohydrates that sustain heterotrophic bacteria [41,42]. Furthermore, the oligotrophic condition of the rainwater tank not exposed to sunlight, therefore with less bacteria due to lack of food, might have accentuated the difference in the plate counts of the two tank [22].

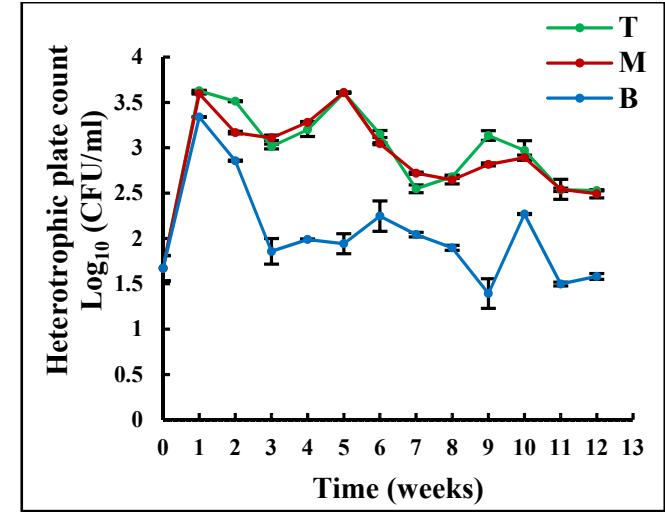

(a)

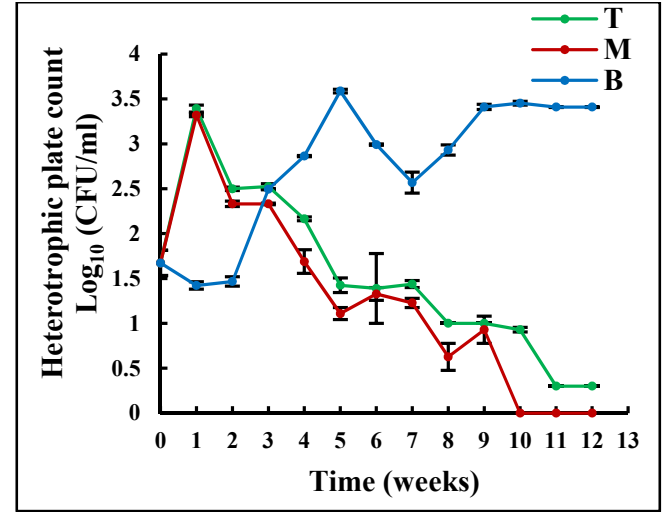

(b)

Figure 5. Variation in suspended heterotrophic bacteria (a) in TES and (b) in TNES at different water depths over time (T: top, M: middle, and B bottom).

Table 3. Comparison of the growth rate, coefficient of determination $\mathrm{R}^{2}$, and $95 \% \mathrm{CI}$ of suspended heterotrophic bacteria in the TES and TNES at different water depths.

\begin{tabular}{ccccccc}
\hline Water Depths & \multicolumn{3}{c}{ Tank Exposed to Sun } & \multicolumn{3}{c}{ Tank Not Exposed to Sun } \\
\hline & Rate $\left.\mathbf{( d}^{-\mathbf{1}}\right)$ & $\mathbf{R}^{\mathbf{2}}$ & $\mathbf{9 5 \%} \mathbf{C I}$ & Rate (d $\mathbf{d}^{\mathbf{- 1})}$ & $\mathbf{R}^{\mathbf{2}}$ & $\mathbf{9 5 \%} \mathbf{C I}$ \\
\hline Top & -0.03 & 0.57 & {$[-0.039-0.019]$} & -0.26 & 0.97 & {$[-0.305-0.215]$} \\
Middle & -0.03 & 0.48 & {$[-0.037-0.014]$} & -0.30 & 0.98 & {$[-0.340-0.256]$} \\
Bottom & -0.17 & 0.97 & {$[-0.162-0.148]$} & 0.02 & 0.38 & {$[0.0100 .032]$} \\
\hline
\end{tabular}

The effect of time on the number of SB was significant, with greenhouse Geisser $\mathrm{F}$ $(1.33)=130.245, p<0.001$ for TES and F $(1.33)=90.250, p<0.001$ for TNES. Coombes et al. (2006) also reported that the bacterial counts in stored rainwater diminish over time due to sedimentation, natural death, and bacterial attachment to the surface. Besides, the main effect of water depth on the average SB plate counts across the time is also significant, with a Greenhouse Greisser F (3.33) = 17.839, $p<0.001$, and F $(3.33)=130.871, p<0.001$ respectively in TES and TNES. 
Changes in the amount of SB in TES and TNES showed different trends at varying depths (Figure 5). In the TES, suspended plate counts were higher at the top and middle levels, and their numbers decreased during the experimental period at all water depths. Furthermore, the pairwise comparison indicated a significant difference only between the top and bottom level $(p<0.01)$ as well as middle and bottom level $(p<0.01)$. This stratification in the number of suspended heterotrophic bacteria is similar to a previous study conducted by Spinks et al. (2007), which explained that a potential reason for these findings could be the occurrence of thermal gradient and difference of bacteria buoyancy [19]. These factors may disturb the settlement of bacteria and slower the decay rate of bacteria at the upper level [19]. In the TNES, a gradual decrease in the number of bacteria at the top and middle levels was observed over time, with opposite trend observed at the bottom level. Also, statistical differences were observed between all the water depths $(p<0.05)$ This phenomenon can be attributed to the sedimentation of particle-attached bacteria in water not exposed to visible light, which eventually increases the number of bacteria at the bottom [18]. Furthermore, natural sedimentation, biofilm formation, and bacterial death reduce bacterial counts in the water body $[12,18]$.

Similarly, a non-linear regression with exponential function was used to estimate the decay rate of the SB. The result is summarized in Table 3.

\subsection{Effect of Visible Light on Physiochemical Paramters}

The $\mathrm{pH}$, TDS, and DO concentration were not affected by different water depths, as shown in Table 4. The difference in temperature between the top and bottom levels was around $1^{\circ} \mathrm{C}$ for more than half of the experimental period and the temperature ranged from 20.7 to $28.9^{\circ} \mathrm{C}$. Heterotrophic bacteria grow rapidly when the temperature ranges between 20 and $30^{\circ} \mathrm{C}$; that is higher the temperature, faster the replication [41,42]. The difference in temperature between the TES and TNES was approximately $1.5^{\circ} \mathrm{C}$, as depicted in Table 4, and was not statically significant. A noticeable difference in the physiochemical characteristics of water between the tanks was the slightly higher concentration of dissolved oxygen in the TES. This difference was possibly due to photosynthesis by phototrophs in the presence of visible light [43].

Table 4. Variation in the physiochemical parameters of rainwater: $\mathrm{pH}$, temperature, total dissolved solids (TDS), and dissolved oxygen concentration.

\begin{tabular}{|c|c|c|c|c|c|c|}
\hline \multirow{2}{*}{ Physiochemical Parameters } & & \multicolumn{2}{|c|}{ Tank Exposed to Sun } & \multicolumn{2}{|c|}{ Tank Not Exposed to Sun } & \multirow{2}{*}{$\begin{array}{c}\text { Average Difference } \\
\text { between TES and TNES }\end{array}$} \\
\hline & & Min & $\operatorname{Max}$ & Min & Max & \\
\hline \multirow{3}{*}{$\mathrm{pH}$} & Top & 5.42 & 8.29 & 5.97 & 8.4 & $0.48 \pm 0.4$ \\
\hline & Middle & 4.9 & 8.29 & 5.72 & 7.95 & $0.46 \pm 0.4$ \\
\hline & Bottom & 4.09 & 7.83 & 6.07 & 7.83 & $0.49 \pm 0.4$ \\
\hline \multirow{3}{*}{ Temperature $\left({ }^{\circ} \mathrm{C}\right)$} & Top & 21.9 & 28.9 & 20.3 & 27 & $1.51 \pm 1.0$ \\
\hline & Middle & 20.2 & 28.9 & 20.6 & 27 & $1.34 \pm 0.9$ \\
\hline & Bottom & 20.7 & 28.6 & 20 & 26.9 & $1.39 \pm 1.0$ \\
\hline \multirow{3}{*}{ Dissolved oxygen (mg/L) } & Top & 5.28 & 8.94 & 5.28 & 7.54 & $1.26 \pm 0.4$ \\
\hline & Middle & 5.28 & 8.94 & 5.28 & 7.56 & $1.24 \pm 0.4$ \\
\hline & Bottom & 5.28 & 8.7 & 5.28 & 7.44 & $1.31 \pm 0.5$ \\
\hline \multirow{3}{*}{ Total dissolved solid (mg/L) } & Top & 41 & 57 & 37 & 57 & $4.33 \pm 3.8$ \\
\hline & Middle & 38 & 57 & 35 & 60 & $4.58 \pm 4.4$ \\
\hline & Bottom & 31 & 57 & 39 & 57 & $3.08 \pm 2.7$ \\
\hline
\end{tabular}

\subsection{Limitation of the Research and Further Study Needed}

This study has some limitations. Firstly, the microbial species that compose the SAB and SB at both TES and TNES condition were not identified, so it is not possible to explain the exact reasons why such phenomena occurred. Secondly, although the microbial activity is a function of various factors, such as color of the tank, TDS of the water in the tank, the 
surface to volume (S/V ratio), dosage of disinfectant, and temperature, this study focused only on the effect of visible light.

Therefore, we recommend conducting further studies characterizing the types of organisms and microbial species in SAB and SB by using PCR tests. Furthermore, other important factors that influence the microbial quality in rainwater tanks.

\section{Conclusions}

The study experimentally investigated the effect of visible light on microbiological and physicochemical quality of harvested rainwater. The bacterial count of SB decreased faster at TNES than TES case, resulting in a better microbial quality at TNES. The number of SAB decreased over time, when it is not exposed to the visible light, while it remained stable when exposed to visible light. There was no big difference between TES and TNES in other physicochemical parameters except that the total organic carbon and concentration of dissolved oxygen were higher in TES than in TNES. Overall, the water quality can be maintained well without the effect of visible light.

From this research, it is possible to suggest a practical implication in the design and operation of typical household rainwater tanks to maintain a good water quality. The storage should be installed to avoid penetration of visible light by putting it under a shade or cover the opening. Disinfection in the tank should be avoided to maintain the microbial balance and self-purification in the rainwater tank.

Some limitations of this research are identified, and further research need is suggested to find easy ways to maintain good water quality in household rainwater harvesting tanks in developing countries and developed countries as well.

Author Contributions: Conceptualization, V.A.R., M.K. and M.H.; methodology, V.A.R., M.K. and M.H.; review and editing, M.K. and M.H.; visualization, M.H.; supervision, M.H.; project administration, M.H.; funding acquisition, M.H. All authors have read and agreed to the published version of the manuscript.

Funding: This research was funded by the Science and Technology Support Program through the National Research Foundation of Korea (NRF) funded by the Ministry of Science and ICT (MSIT) (grant number: NRF-2018K1A3A9A04000025).

Institutional Review Board Statement: Not applicable.

Informed Consent Statement: Not applicable.

Data Availability Statement: Not applicable.

Acknowledgments: The authors would like to thank the members of the Institute of Construction and Environmental Engineering (ICEE) at Seoul National University for their advice and support throughout this research.

Conflicts of Interest: The authors declare no conflict of interest.

\section{References}

1. UN. World Fertility and Family Planning 2020: Highlights; United Nations, Department of Economic and Social Affairs, Population Division: New York, NY, USA, 2020; Available online: https://www.un.org/development/desa/pd/sites/www.un.org. development.desa.pd/files/files/documents/2020/Aug/un_2020_worldfertilityfamilyplanning_highlights.pdf (accessed on 17 April 2021).

2. Water UN. Coping with Water Scarcity a Strategic Issue and Priority for System-Wide Action; New York, NY, USA, 2006; Available online: https://www.preventionweb.net/publications/view/1770 (accessed on 17 April 2021).

3. World Water Assessment Programme. The United Nations World Water Development Report. New York, NY, USA, 2018. Available online: www.unwater.org/publications/\%0Aworld-water-development-report-2018/ (accessed on 17 April 2021).

4. Bernard, B.; Joyfred, A. Contribution of Rainfall on Rooftop Rainwater Harvesting and Saving on the Slopes of Mt. Elgon, East Africa. Sci. World J. 2020, 2020, 7196342. [CrossRef]

5. Yannopoulos, S.; Giannopoulou, I.; Kaiafa-Saropoulou, M. Investigation of the current situation and prospects for the development of rainwater harvesting as a tool to confront water scarcity worldwide. Water 2019, 11, 2168. [CrossRef]

6. Rainwater Harvesting 101. Available online: https://www.watercache.com/education/rainwater-harvesting-101 (accessed on 24 April 2021). 
7. Thomas, T.H. The limitations of roofwater harvesting in developing countries. Waterlines 2014, 33, 139-145. [CrossRef]

8. UN Habitat for a Better Future: Blue Drop Series on Rainwater Harvesting and Utilisation-Book 3 Project Managers and Implemetation Agency. Available online: https:/ / unhabitat.org/blue-drop-series-on-rainwater-harvesting-and-utilisation-book3project-managers-and-implemetation-agency/ (accessed on 23 April 2021).

9. Lee, J.Y.; Bak, G.; Han, M. Quality of roof-harvested rainwater-Comparison of different roofing materials. Environ. Pollut. 2012, 162, 422-429. [CrossRef] [PubMed]

10. Alim, M.A.; Rahman, A.; Tao, Z.; Samali, B.; Khan, M.M.; Shirin, S. Suitability of roof harvested rainwater for potential potable water production: A scoping review. J. Clean. Prod. 2020, 248, 119226. [CrossRef]

11. Al-Batsh, N.; Al-Khatib, I.A.; Ghannam, S.; Anayah, F.; Jodeh, S.; Hanbali, G.; Khalaf, B.; van der Valk, M. Assessment of rainwater harvesting systems in poor rural communities: A case study from Yatta Area, Palestine. Water 2019, 11, 585. [CrossRef]

12. Coombes, P. Key Messages from a Decade of Water Quality Research into Roof Collected Rainwater Supplies; Burswood Convention Centre Perth: Burswood, WA, Australia, 2006; pp. 1-9. Available online: http:/ / urbanwatercyclesolutions.com/wp-content/ uploads/2014/01/RWT_WQ_insights1.pdf (accessed on 20 February 2021).

13. Kim, M.; Han, M. Role of Biofilm in Rainwater Tank. Microb. Biofilms. Importance Appl. 2016. [CrossRef]

14. Van Der Merwe, V.; Duvenage, S.; Korsten, L. Comparison of biofilm formation and water quality when water from different sources was stored in large commercial water storage tanks. J. Water Health 2013, 11, 30-40. [CrossRef]

15. Evans, C.A.; Coombes, P.J.; Dunstan, R.H.; Harrison, T. Extensive bacterial diversity indicates the potential operation of a dynamic micro-ecology within domestic rainwater storage systems. Sci. Total Environ. 2009, 407, 5206-5215. [CrossRef]

16. Evison, L.; Sunna, N. Microbial regrowth in household water storage tanks. J. Am. Water Work Assoc. 2001, 93, 85-94. [CrossRef]

17. Kim, M.; Han, M. Composition and distribution of bacteria in an operating rainwater harvesting tank. Water Sci. Technol. 2011, 63, 1524-1530. [CrossRef]

18. Amin, M.T.; Kim, T.; Amin, M.N.; Han, M.Y. Effects of Catchment, First-Flush, Storage Conditions, and Time on Microbial Quality in Rainwater Harvesting Systems. Water Environ. Res. 2013, 85, 2317-2329. [CrossRef]

19. Spinks, A.T. Water Quality, Incident Treatment Train Mechanism and Health Risks Associated with Rainwater Harvesting System in Australia; University Newcastle: Newcastle, Australia, 2007.

20. Peter, J.; Spinks, A.; Evans, C.; Dunstan, H. Performance of Rainwater Tanks at an Inner City House in Carrington NSW during a Drought; Callaghan, Newcastle, Australia, 2004; Available online: https:/ /www.researchgate.net/publication/228583398_Performance_ of_Rainwater_Tanks_at_an_Inner_City_House_in_Carrington_NSW_During_a_Drought (accessed on 20 February 2021).

21. Fu, Y.; Peng, H.; Liu, J.; Nguyen, T.H.; Hashmi, M.Z.; Shen, C. Occurrence and quantification of culturable and viable but non-culturable (VBNC) pathogens in biofilm on different pipes from a metropolitan drinking water distribution system. Sci. Total Environ. 2021, 764, 142851. [CrossRef]

22. Kim, M.; Han, M. Role of biofilms in improving microbial quality in rainwater tanks. Desalin. Water Treat. 2015, 53, 2579-2584. [CrossRef]

23. Santos, A.L.; Henriques, I.; Gomes, N.C.M.; Almeida, A.; Correia, A.; Cunha, A. Effects of ultraviolet radiation on the abundance, diversity and activity of bacterioneuston and bacterioplankton: Insights from microcosm studies. Aquat. Sci. 2011, 73, 63-77. [CrossRef]

24. Hockberger, P.E. A History of Ultraviolet Photobiology for Humans, Animals and Microorganisms. Photochem. Photobiol. 2002, 76, 561. [CrossRef]

25. Ruiz-González, C.; Simó, R.; Sommaruga, R.; Gasol, J.M. Away from darkness: A review on the effects of solar radiation on heterotrophic bacterioplankton activity. Front. Microbiol. 2013, 4, 131. [CrossRef]

26. Schmidt, H.; Thom, M.; Wieprecht, S.; Manz, W.; Gerbersdorf, S.U. The effect of light intensity and shear stress on microbial biostabilization and the community composition of natural biofilms. Res. Rep. Biol. 2018, 9, 1-16. [CrossRef]

27. Dessie, A.; Alemayehu, E.; Mekonen, S.; Legesse, W.; Kloos, H.; Ambelu, A. Solar disinfection: An approach for low-cost household water treatment technology in Southwestern Ethiopia. J. Environ. Health Sci. Eng. 2014, 12, 1-6. [CrossRef]

28. Diebel, J.; Norda, J.; Kretchmer, O. Average Weather in Seoul. Available online: https://weatherspark.com/m/142033/8 / Average-Weather-in-August-in-Seoul-South-Korea\#Sections-Sources (accessed on 20 April 2021).

29. Kobayashi, H.; Oethinger, M.; Tuohy, M.J.; Procop, G.W.; Bauer, T.W. Improved detection of biofilm-formative bacteria by vortexing and sonication: A pilot study. Clin. Orthop. Relat. Res. 2009, 467, 1360-1364. [CrossRef] [PubMed]

30. Stiefel, P.; Rosenberg, U.; Schneider, J.; Mauerhofer, S.; Maniura-Weber, K.; Ren, Q. Is biofilm removal properly assessed? Comparison of different quantification methods in a 96-well plate system. Appl. Microbiol. Biotechnol. 2016, 100, 4135-4145. [CrossRef] [PubMed]

31. Wilson, C.; Lukowicz, R.; Merchant, S.; Valquier-Flynn, H.; Caballero, J.; Sandoval, J.; Okuom, M.; Huber, C.; Brooks, T.D.; Wilson, E.; et al. Quantitative and Qualitative Assessment Methods for Biofilm Growth: A Mini-review HHS Public Access. Res. Rev. J. Eng. Technol. 2017, 6. Available online: https://www.ncbi.nlm.nih.gov/pmc/articles/PMC6133255/ (accessed on 17 April 2021).

32. Crystal Violet Staining Solution (0.5\%); Cold Spring Harbor Protocols: New York, NY, USA, 2016.

33. Lee, D.K. Data transformation: A focus on the interpretation. Korean J. Anesthesiol. 2020, 73, 503-508. [CrossRef]

34. Hammouri, H.M.; Sabo, R.T.; Alsaadawi, R.; Kheirallah, K.A. Handling skewed data: A comparison of two popular methods. Appl. Sci. 2020, 10, 6247. [CrossRef] 
35. Paula, A.J.; Hwang, G.; Koo, H. Dynamics of bacterial population growth in biofilms resemble spatial and structural aspects of urbanization. Nat. Commun. 2020, 11, 1-4. [CrossRef]

36. Tu, C.; Chen, T.; Zhou, Q.; Liu, Y.; Wei, J.; Waniek, J.J.; Luo, Y. Biofilm formation and its influences on the properties of microplastics as affected by exposure time and depth in the seawater. Sci. Total Environ. 2020, 734, 139267. [CrossRef] [PubMed]

37. Agustí, S.; WKrause, J.A.; Marquez, I.; Wassmann, P.; Kristiansen, S.; Duarte, C.M. Arctic (Svalbard islands) active and exported diatom stocks and cell health status. Biogeosciences 2020, 17, 35-45. [CrossRef]

38. Misic, C.; Covazzi Harriague, A. Development of marine biofilm on plastic: Ecological features in different seasons, temperatures, and light regimes. Hydrobiologia 2019, 835, 129-145. [CrossRef]

39. De Tender, C.; Devriese, L.I.; Haegeman, A.; Maes, S.; Vangeyte, J.; Cattrijsse, A.; Dawyndt, P.; Ruttink, T. Temporal Dynamics of Bacterial and Fungal Colonization on Plastic Debris in the North Sea. Environ. Sci. Technol. 2017, 51, 7350-7360. [CrossRef]

40. Hameed, A.; Lai, W.A.; Shahina, M.; Stothard, P.; Young, L.S.; Lin, S.Y.; Sridhar, K.R.; Young, C.C. Differential visible spectral influence on carbon metabolism in heterotrophic marine flavobacteria. FEMS Microbiol. Ecol. 2020, 96, fiaa011. [CrossRef]

41. Villa, F.; Pitts, B.; Lauchnor, E.; Cappitelli, F.; Stewart, P.S. Development of a laboratory model of a phototroph-heterotroph mixed-species biofilm at the stone/air interface. Front. Microbiol. 2015, 6, 1251. [CrossRef] [PubMed]

42. Valverde, A.; Makhalanyane, T.P.; Seely, M.; Cowan, D.A. Cyanobacteria drive community composition and functionality in rock-soil interface communities. Mol. Ecol. 2015, 24, 812-821. [CrossRef] [PubMed]

43. Roeselers, G.; Loosdrecht, M.C.M.V.; Muyzer, G. Phototrophic biofilms and their potential applications. J. Appl. Phycol. 2008, 20, 227-235. [CrossRef] [PubMed] 